\title{
Conserving Modern Architectural Heritage: Review on First Numune Hospitals of Turkey \\ Mehmet Şener ${ }^{*}$ Emre Kishalı **
}

\footnotetext{
Abstract

Purpose

The new political approaches followed after the establishment of republic transformed the basic characteristics of many different dynamics in Turkey ranging from education and industry to art and architecture. The arrangements related to health services hold an important place among these fields and the great transformations seen in healthcare services necessitated the construction of hospital buildings with contemporary architectural qualities. In this framework, new hospital buildings known as "Numune" (Sample) Hospitals were established in Ankara, Diyarbakır, Erzurum and Sivas cities in 1924 to be good examples for further hospital buildings. In this context, the historical evolutions, architectural characteristics and current situations of these Numune hospitals are examined in this study together with an analysis of all the changes and interventions they were exposed to from past to present. This study aims to clarify the historical importance of Numune hospitals in question, address the changes they have undergone to date, criticize the interventions in the context of architectural history and conservation disciplines, and put forward various suggestions related to such disciplines. The search of the ways to provide the interrelationship of these buildings with the rapidly evolving current world by referring to the contemporary methods of
}

Keywords: Health facility architecture, modern architectural heritage, numune hospitals, conservation

*Assist. Prof. Dr. in Architecture department in Kocaeli University, Turkey

E-mail: germinal_msener@yahoo.com ORCID No: https://orcid.org/00000001-8137-8547

${ }^{* *}$ Assist. Prof. Dr. in Architecture department in Kocaeli University, Turkey

E-mail: emre.kishali@kocaeli.edu.tr ORCID No: https://orcid.org/00000002-1740-5042 
different disciplines, constitutes one other basic aim of this study. The applications of the public authority of health services; namely the Ministry of Health- and the other efficient dynamics related with the conservation of these buildings are also critically evaluated with respect to their roles on the sustaining of the architectural and historial values of these buildings.

\section{Design/Methodology/Approach}

The problems in preserving the original characteristics and showing respect to the historical values of these buildings are discussed by using the instruments and concepts of architectural history and conservation disciplines. Besides, some strategies are proposed for the preservation of these buildings with an awareness of the current conditions of health services in Turkey, and the possibility of the conflict between today's conservation practices and health facility standards.

\section{Findings}

Taking into account contemporary approaches and the advanced conservation techniques being employed today, this study indicates that it is possible to make use of these structures by transforming their functions and maintaining their authentic values through proper applications. It is also expressed that a well-defined framework regarding that which structures are to be conserved according to which criteria could not be created, and that the decision-making mechanism focused solely on the conservation of the oldest structures.

\section{Practical Implications}

Some refunctioning and remediation strategies are presented for conserving the historical values of these Numune hospitals, while also improving their conditions as far as possible.

\section{Social Implications}

The concepts of heritage and value should be defined in a broader contextual framework and conservation principles should be revised according to these definitions.

\section{Originality/Value}

Considering these buildings serve as cultural bridges extending from the Ottoman era to the present and have important places in the historical development of healthcare facility architecture in Turkey, they hold symbolic values within the context of Turkish architectural history and heritage.

\section{INTRODUCTION}

With new architectural movements and the introduction of new constructions materials and technologies, the first years of the Republic witnessed radical changes in the field of architecture, as in all aspects of social life. Numerous public buildings were constructed by the government in pursuit of its goal to change the architectural tradition and knowledge inherited from the Ottoman era, leading to the production of a national and modern architecture that represented the ideals of young Republic. Additionally, policies that led to radical changes in social dynamics, such as those related to healthcare, education, public works, etc. were implemented, which, in turn, resulted in the 
provision of public services in the said areas, stronger institutionalization, the introduction of more modern technologies, and the adoption of different architectural approaches in the public buildings constructed in this period. As part of these efforts, comprehensive reforms were instituted in the field of healthcare, and contemporary structures that were able to respond to new applications started to be constructed simultaneously. The "Numune" (Sample) hospitals constructed in the early years of the Republic (1924), some of which were established under the orders of Atatürk, were the most important of the new healthcare structures, having been envisaged to represent the new healthcare system, and the Republic as a whole.

Since the foundation of the Republic, many of these numune state hospitals have been constructed in Turkey, the first of which were established in Ankara, Diyarbakır, Erzurum and Sivas in 1924 (fully equipped, and with a 150-bed capacity). Some of these structures that are still operational today, although they have been subjected to countless demolitions, interventions and transformations over time, were converted from the Memleket or Gureba (poor and desolate) hospitals constructed in the Ottoman era that were run by local administrations, and so today serve as cultural bridges extending from the Ottoman era to the present. Also serving as historical documentation of healthcare and the architectural characteristics of hospitals in the Ottoman era, these structures hold an important place in the historical development of Turkish healthcare facilities, serving as examples for the hospitals to be constructed in the years to come. Considering all these characteristics as a whole, these numune hospitals, as the first and most concrete indicators of the reforms instituted in the field of healthcare, hold symbolic value within the context of Turkish architectural history and national architectural heritage, and they can thus be considered as items of cultural heritage that are of historical importance, and so worthy of conservation.

Analyses to be conducted on the changes and transformations undergone by numune hospitals in various cities and under various circumstances, in addition to their value and importance, will facilitate multifaceted discussions in many academic disciplines, particularly in those of conservation and architectural history. The fact that numune hospitals, once Gureba hospitals, were altered through the addition of modern hospital equipment, increase in their numbers, some developments in their structures, and the demolishment of other numune hospitals constructed over time reveals the existence of a historical process that should be evaluated in a multidimensional manner. Accordingly, this study approaches 
these structures with respect to their historical importance and architectural characteristics, as well as the interventions that they have undergone over time, the problems experienced in this context, and suggestions for conservation and renovation works, as required by their value as heritage. As one of the main objectives of the study is to understand the impact of Republican policies on Anatolia, focus is particularly on the first group of numune hospitals that were established in Anatolia outside Istanbul, being those that opened in 1924, the interventions and annexations made to them over time, and their current status from the perspective of architectural history and conservation.

The study clarifies the historical importance and architectural characteristics of the structures in question, addresses the changes they have undergone to date in every aspect, criticizes the interventions in the context of architectural history and conservation disciplines, and puts forward various suggestions related to such disciplines. Taking into account the problems that may be encountered in ensuring that the structures in question can meet current healthcare standards, as well as the current level of development of healthcare architecture and their continued use in their unique functions, some refunctioning, remediation and conservation strategies are presented that are aimed at conserving their historical value and unique identities, while also improving their conditions as far as possible.

\section{FIRST GROUP OF NUMUNE HOSPITALS: ANKARA, DIYYARAKIR, ERZURUM AND SIVAS}

One of the most significant steps taken by the Republican government, which had inherited an insufficient healthcare infrastructure from the Ottoman Empire that included less than 2,000 hospital beds, around 1,000 doctors and three state hospitals with a total of 950 beds, was to open Numune Hospitals with a view to improving the system (Sayek, 1998). The goal in constructing numune hospitals was expressed for the first time in the "healthcare program developed by the Ministry of Health and Social Welfare for being a guide to and setting an example for local administrations (special provincial administrations and municipalities) due to the insufficiency of healthcare institutions and the lack of modern equipment in the country", specified under the name "Anatolian Numune Hospitals" in the budget of the Ministry of Health and Social Welfare adopted by the Grand National Assembly of Turkey on March 18, 1924, and it was stated that "these healthcare institutions would be financed from the government budget and be subordinated directly to the Ministry of Health" (Altay, 2015). As a consequence of the negotiations held in the Grand National Assembly of Turkey, "it was decided that four numune hospitals would be opened in 
Ankara, Sivas, Erzurum and Diyarbakır, and that these institutions would directly be administrated by the Ministry of Health and be financed from the government budget" (Altay, 2015)

As their name suggests, these hospitals were intended to set a good example for the many new hospitals to be constructed in the years to come in architectural and functional terms. Aside from the fully equipped numune hospitals opened in the abovementioned provinces, various healthcare institutions under the names "Nation, State, Homeland and Municipality hospitals" were entered into service in other provinces during the early Republican period, (Başar, 1979) and later some of these would go on to become numune hospitals.

\section{Ankara Numune Hospital}

The Ankara Numune Hospital was started out in life in the second half of the 1800s under the name Gureba Hospital, but became one of the first groups of numune hospitals to be established pursuant to the law enacted in 1924. The hospital started to offer services in three individual structures, with blocks added afterwards to the original structure that were designed in the national architectural style (hipped roof, arch windows, use of roof tiles, window jambs, stone covered subbasement, etc.), as the most common style among the public structures constructed in the late Ottoman era, but failed to meet the needs (Figure 1). On the site of such structures, the "Refik Bey (Saydam) Pavilion" started to be constructed, to have a capacity of 50 beds, in 1927, and construction was completed in six years. The facility entered into service under the name the "Ismet Paşa Pavilion", with a capacity of 300 beds (Figure 2). The structure designed by Austrian architect Robert Oerley and constructed in 1933 is the only structure to have survived, bearing characteristics of Central European architecture with its "tile covered pitched roof and dormer windows", its entrance, taking the form of a hexagonal protrusion on the facade, and its monumental appearance (Cengizkan, 2011). However, the structure also bears traces of the national architectural style with its sub-basement covered with Ankara stones on its facade. The reinforced concrete skeleton of the main block of the Ankara Numune Hospital, construction of which started in 1932 and was completed in 1933 on the 10th anniversary of the Republic, was constructed by German company Riedlich und Berger, and its electricity and water installation, elevator and plaster/painting works were carried out by Vehbi Koç who had been awarded the contract together with the Burla Brothers (Dündar, 2006). 
Figure 1. (Left) First Numune Hospital transformed from Ankara Gureba 1881 (SBÜ Ankara Numune Training and Research Hospital Archive); (Middle and Right) additional blocks after 1924 (Arlet Natali Avazyan Archive).

Figure 2. Robert Oerley, The 300bed Ismet Paşa Pavilion, which is still operational, 1933, Ankara (SB̈̈ Ankara Numune Eğitim ve Araştırma Hastanesi).

Figure 3. (Left) Robert Oerley, Ankara Numune Hospital site plan; (Right) Current view of Numune Hospital (Mehmet Şener Archive, 2018).
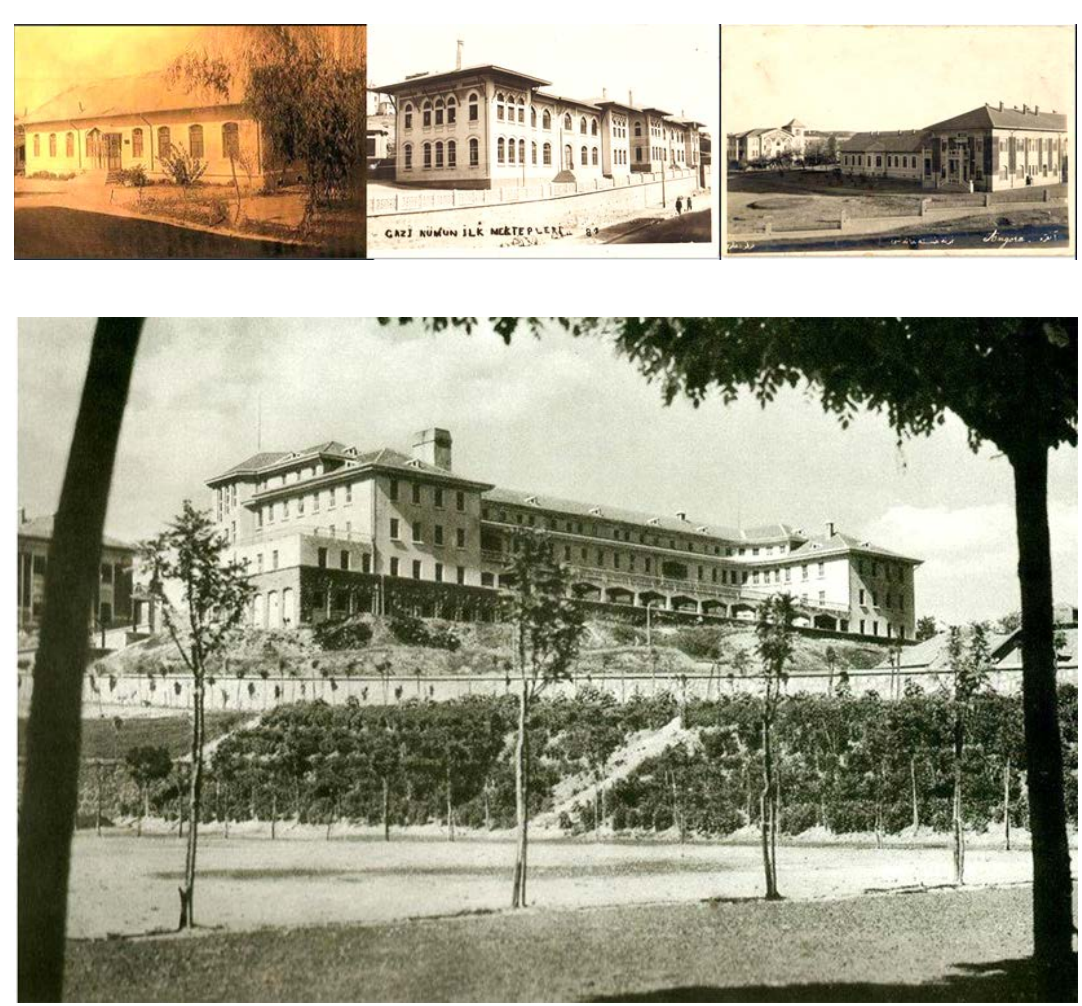

It was also one of the largest and most costly structures in Ankara at the time, and today is located within the Ankara Numune Training and Research Hospital complex, where it has functioned as a healthcare facility until it was transferred to Bilkent City Hospital in May 2019. It has provided services under the name "Block B", along with other blocks that have been added within the historical process, and houses classrooms, administrative units and inpatient clinics (Figure 3). On a planimetric drawing of the structure, the symmetrical and function-oriented organization that was implemented within the framework of the Western design approach that was quite popular for public structures of the time can still be observed.

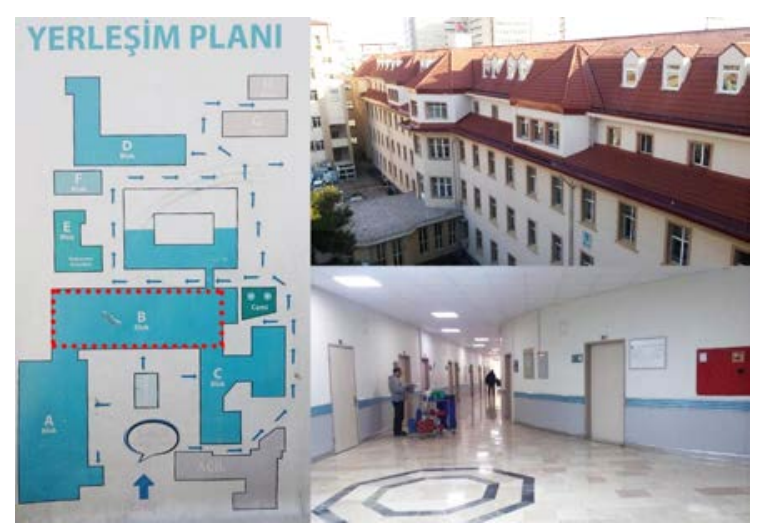

\section{Diyarbakır Numune Hospital}

The Diyarbakır Numune Hospital was established in 1924 by the Ministry of Health and Social Aid, following repairs and additions 
made to the single-story Gureba Hospital that opened with a capacity of 25 beds in 1884, and was the first numune hospital to be opened in the South-eastern Anatolia region. A 102-bed hospital was constructed with a total cost of 150,000 liras, and three pavilions were constructed with a total cost of 25,000 liras in the same year (Çağlayan, 2013). After the hospital burned down in 1936, it was reconstructed and reopened with a total capacity of 200 beds on March 21, 1939 (Çağlayan, 2013). The structure is still in operation today, housing such healthcare departments as a psychiatry clinic. The building carries the characteristics of the national architectural style of the time, with a hipped roof with eaves, a raised entrance with stairs, cut stone jambs emphasizing the column axes on the facade, its window typology and its symmetrical facade (Figure 4 and 5). The arch above the entrance door, designed in an Umayyad/Arabic architectural style, highlights the regional influences in the design of the structure. The Diyarbakır Numune Hospital comprised eight separate buildings in 1939, and although they were more or less constructed simultaneously, only one building could be conserved, with the remaining structures being demolished at various times.

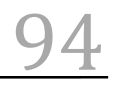

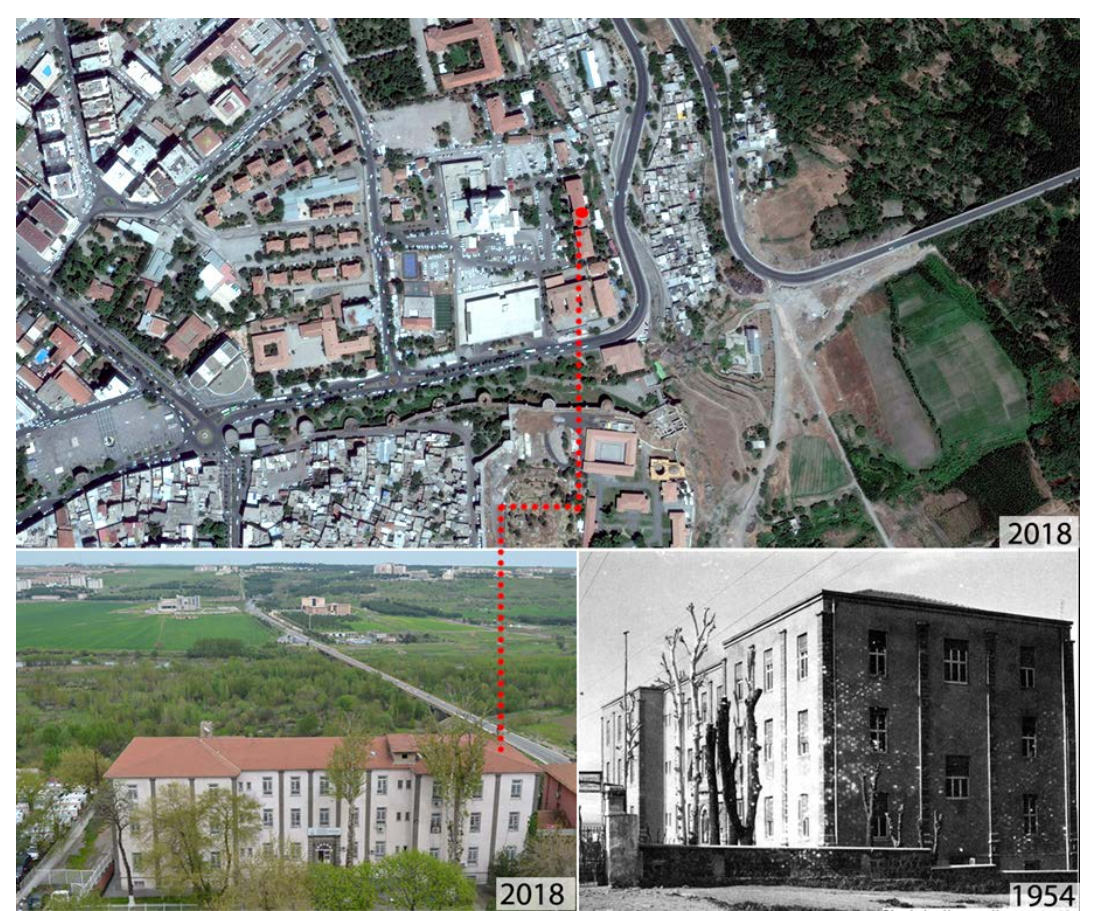

Figure 4. (Upper) current aerial view of Diyarbakır Numune Hospital in 2018, Diyarbakır; (Lower Left) the view of the hospital (Rubin Karakoyunlu Archive, 2018); (Lower Right) the view in 1939 (Arlet Natali Avazyan, 1939). 
Figure 5. Diyarbakır Numune Hospital in 2018 (Rubin Karakoyunlu Archive: 2018).

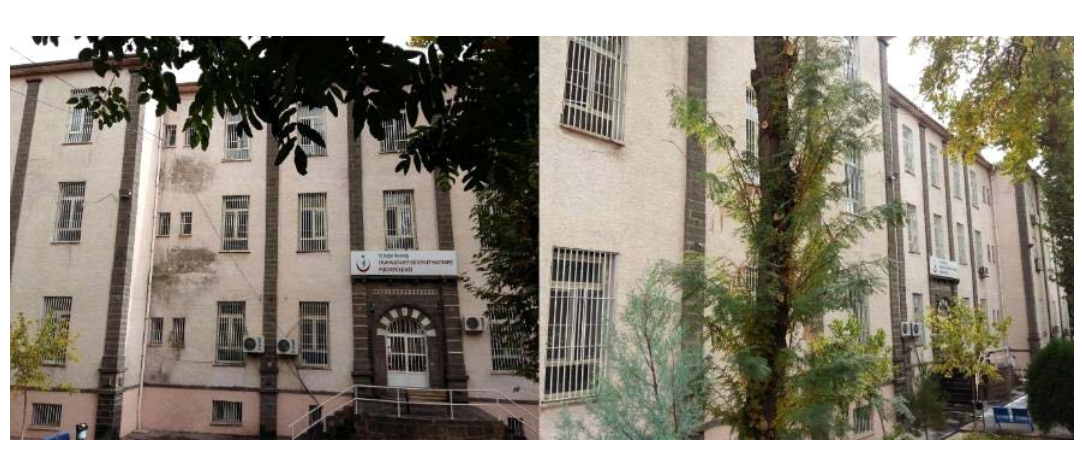

\section{Erzurum Numune Hospital}

The Erzurum Numune Hospital was a continuation of the Gureba Hospital that had been put into service in 1904 during the reign of Sultan Abdulhamid II. The foundation of the Gureba Hospital was laid in 1902 using funds collected from the public under an initiative launched by Mayor Şerif Efendi (Küçükuğurlu, 2016). The hospital opened in the same year when Abdulhamid II acceded to the throne, and started providing services under the name Hamidiye Gureba Hospital. It had a floor area of 593 square meters, comprising a basement, ground and first floors and an attic. According to Küçükuğurlu (2016), the requests were made over time to construct an annex to the hospital with the aim of increasing its capacity to 50 beds, and to repair the original structure, although all such requests were declined by the central government in Istanbul. As a result, the structure became dilapidated and fell into such a state that in 1912 it was no longer deemed appropriate for the provision of healthcare services. Plans were made to hand the structure over to the military or to use it as an inspection building during World War I, but these never came to fruition. The structure survived thanks to the aid granted by special administrations and the state prior to the proclamation of the Republic, and continued to provide healthcare services as a continuation of the Gureba hospital after changing its name to Erzurum Numune Hospital in 1924 (Küçükuğurlu, 2016).

For the hospital that was opened in 1924 along with the first group of numune hospitals, no further structure was constructed that year, and only its name was changed after it was rendered subordinate to the Ministry of Health. Many healthcare facilities were constructed around it at various times. For example, the foundations of a U-shaped building were laid in 1953 in order to meet the newly emerging needs, and the subsequent building entered into service as a 400-bed hospital following the completion of construction on March 12, 1963 (Başar, 1979). Among these structures, only the first Gureba Hospital was able to be officially registered and survives today (Figure 6). After being used as the Şerif Efendi Polyclinic of the Numune Hospital for many years, the structure was refunctioned as an additional 
service building of the Erzurum Regional Training and Research Hospital (RTRH) in 2010, and was later named as the Şerif Efendi Family Health Center. The structure is built in the national architectural style that was popular in the late Ottoman era and the early Republican period. With its hipped roof and eaves, stone-covered sub-basement, window jambs, arched and stonecovered basement windows, and symmetrical facade design, the structure bears the characteristics of the style of the First National Architecture period.

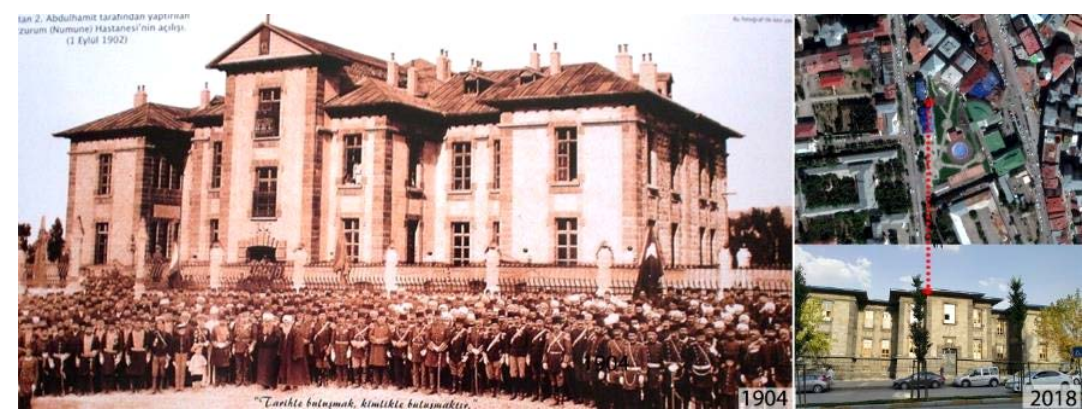

\section{Sivas Numune Hospital}

The Sivas Numune Hospital was moved to various structures and provided services under various different names following its establishment in 1886, up until to the foundation of the Republic. Its final function before being reassigned as a numune hospital was as a building of the American College. As part of the first group of numune hospitals in the Republican period, it started out providing services as a 50-bed hospital in the building to which it moved in 1924 (Budaktaş, 2017).

The Sivas Numune Hospital started to operate under its new name after the 25-bed Memleket Hospital was reassigned to the Ministry of Health (Altay, 2015). It burned down in a fire in 1930, but reopened in a structure that was built in 1952 and that is still standing today, providing services in various structures. The construction of Sivas Numune Hospital started in the 1940s, and it entered into operation following the completion of construction in 1952. The structure's hipped roof and eaves, its neoclassical entrance colonnade, and the window design and arched jambs on its facade indicate that it was designed in the Second National Architecture style that was popular among the public structures of the time (Figure 7). The structure is still operational and provides services today. It was registered in 2016, while the hospital buildings that were constructed around it at various times have all been demolished.
Figure 6. (Left) opening ceremony of the Gureba Hospital 1904 (Küçükuğurlu 2016); (Upper Right) aerial view of hospital; (Lower Right) a current view of Erzurum Numune Hospital (Dilek Okuyucu Archive, 2018). 
Figure 7. (Upper Left) Aerial view of Sivas Numune Hospital in 2018; (Upper Right) in 2016; (Lower Left) Sivas Numune Hospital (Directorate General of Cultural Assets and Museums, Natural and Cultural Assets Conservation Inventory, 1952); (Lower Right) Sivas Numune Hospital (Gülhayat Kılcı Ağraz Archive, 2018).

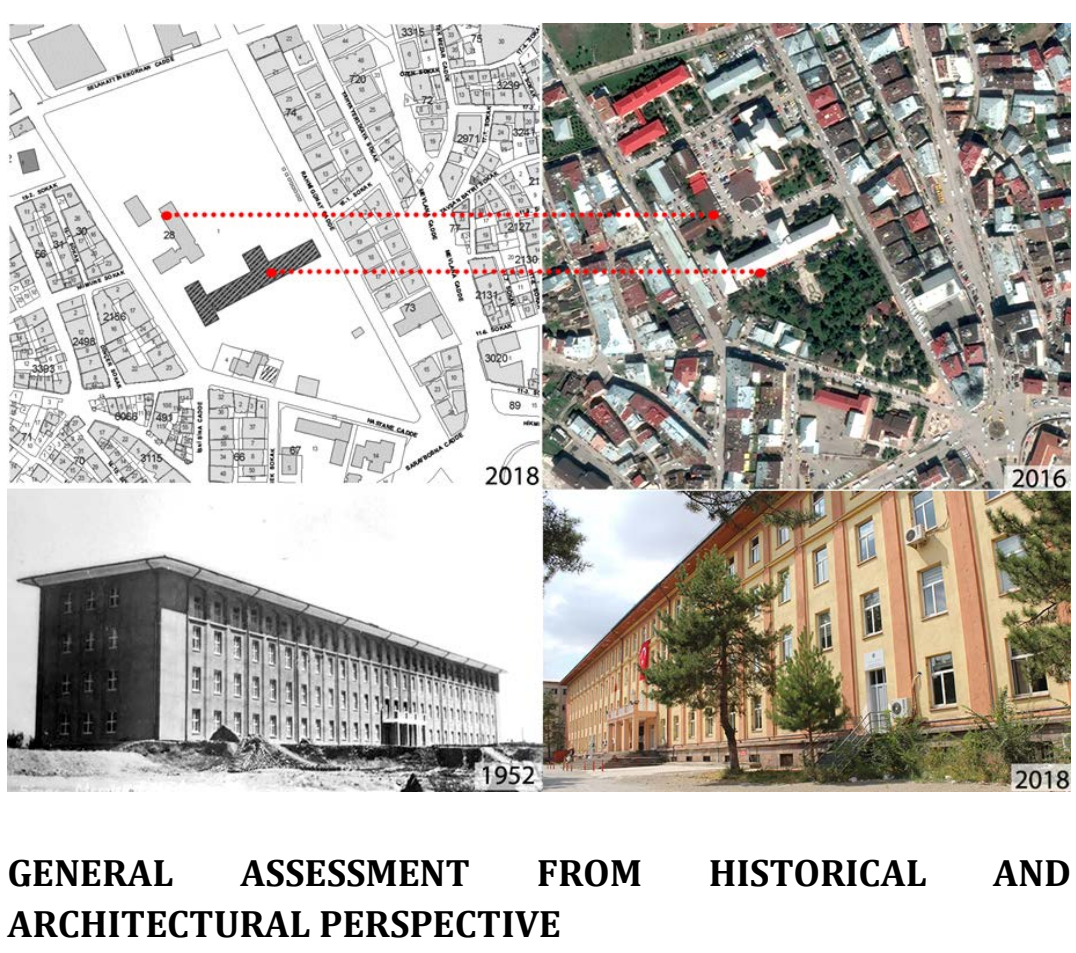

In the first hospitals that opened under the name Gureba Hospitals in the late Ottoman period that were later transformed into "Numune Hospitals" in 1924, it is possible to observe an overall national architectural style (an Ottoman renaissance) based on the principle of "combining elements taken from classical Ottoman architecture with Europe's academic design principles and construction techniques" (Bozdoğan, 2012). The Ottoman architectural details that can be observed on the numune hospitals, as public structures that ensured the propagation of the said architectural styles across Anatolia, including symmetry, roofs with broad eaves, arched windows (some of which are pointed), etc. confirm this notion. These hospitals may be considered as examples of the public structures that "represented the ideals of the new Republic" for some time through such public buildings as government and municipality offices, schools and post offices in provinces like Konya, Izmir, Kütahya and Afyon by which the National Architectural Renaissance of 1920s that started from Ankara, spread across Anatolia (Bozdoğan, 2012).

On the other hand, the numune hospitals that were constructed in addition, or as an alternative, to such structures carry a number of modern architectural features that did not fit in with the said architectural language. These modern structures not only brought about a transformation of architectural language, but also significant innovations in the quality and technologies used in the provision of healthcare services. While the first numune hospitals, established through the transformation of Gureba hospitals, were a continuation of the healthcare approach and architecture of the Ottoman era, the structures constructed 
in place of, or around them, in the following years became the first examples of the implementation of modern architectural approaches in the field of healthcare in Turkish architectural history.

It is possible to attribute the adoption of the national architectural styles in a significant proportion of the hospital buildings to the early Republican period rather than the modern architectural styles that were dominant at the time, to the fact that the Gureba and Memleket hospitals that laid the groundwork for the numune hospitals had been constructed in the national architecture styles that were dominant in late Ottoman architecture, and to the influential role played by the German and Austrian architects who led to the emergence of a Second National Architecture movement in Turkey in the production of such structures.

\section{NUMUNE HOSPITALS IN THE CONTEXT OF THEIR HISTORICAL AND CONSERVATION VALUES AND THE INTERVENTIONS MADE \\ Conservation Values}

The hospitals in Erzurum, Diyarbakır and Ankara entered into service in the buildings of the former Gureba hospitals, while the Sivas Numune Hospital was established in the building of the American College, after providing services in several different buildings during the Ottoman era. Subsequently, various structures were constructed in place of, or around, some of these structures (Ankara and Sivas) in accordance with the new Republic's notion of creating a national identity. It is possible to differentiate between the various intervention approaches made to each numune hospital, such as reuse, reconstruction, and the addition of new structures to, or the enlargement of, the historical buildings. It is important to consider such alterations as a whole alongside the history of healthcare in the country that began to undergo a transformation in the 19th century, the architectural production that was seen in response to such services, and their users, stakeholders and spatial evolution. Additionally, the continuity of architectural value has another meaning in the hospital structures that are focused on human health and continuity of life.

The demographic, political and technological changes that occur within the historical process make interventions into such hospitals and their surroundings that hold historical and cultural value inevitable. In the early years of the Republic, new structures were constructed, while some numune hospitals were transformed from Gureba Hospitals or were created by way of a refunctioning of other structures. Some of these structures are still intact today, while others have been demolished following 
fire or other such reasons. The buildings that were added to the Erzurum and Sivas Numune Hospitals constructed in 1960s no longer exist, having been demolished to be replaced by urban parks. The growing need and trends in new hospitals, in parallel to the health policies and technological developments, resulted in the construction of further healthcare structures next to or around the existing healthcare facilities, such as registered numune hospitals, many of which still survive to date. The reuse of old hospital buildings lays the groundwork for new discussions; and all these discussions and the current state of the numune hospitals displays the necessity of integrated conservation approach and the continuity of values. The relevant health policies and architectural and urban productions such as numune hospitals that emerged as a result of these policies are also important in the sense that they encourage the analysis of hospital constructions from the Republican period, and suggest some necessary conservation applications.

The main reason for the focus on numune hospitals in this study is that these structures involve a multi-component body of values from the phenomena of urban development and cultural memory, to architectural history and conservation practices. Since they hosted "cultural processes of social activities that include remembering and memory-marking" apart from their functional qualities, they gain their "own significances" and "identity"; and inevitably turn into cultural heritages (KamelAhmed, 2015). In this respect, although it is disputable whether they can be considered modern architectural works, they need to be approached from the perspective of a conservation relationship and an architectural history in which focus is on contemporary practices for an asset of architectural heritage that was considered modern at the time of construction. Numune hospitals, which possess almost all of the values associated with structures produced in the modern age is, according to Madran, carry heritage value, such as document value, identity value, architectural value, functional and economic value, and continuity value, and become appropriate tools for architectural history and conservation analyses from multidisciplinary perspectives together with the role of the complicated physical evolution they have undergone in the historical process (Madran, 2006). The fact that the numune hospitals addressed in the study are still being used for the provision of healthcare services, whether directly or indirectly, should be considered as something positive, in the sense that the authentic function of the structures has been retained. 


\section{Problem Analysis: Interventions and Restoration Applications}

When addressed together with the problems related to the conservation of registered structures in Turkey, one can see that these numune hospitals, which have maintained an important place in the provision of healthcare services and the architectural history of the Republican period, have been subjected to various inappropriate interventions as a result of rapid decisions that were made without taking into account their historical, cultural and memorial values. It is somewhat remarkable that some of these structures have never been conserved, that conservation measures were taken for some of them only after various inappropriate interventions, and that although some of them have been conserved, the necessary applications have been made with an inappropriate approach. As a conservation approach, priority has been given to values and approaches prioritizing economic size and use, while the memorial, monumental, historical and architectural values of the structures have been ignored. As a result, while the physical conservation of the registered structures has been ensured to a great extent, the body of complicated and multidimensional values acquired during the historical process of the structures has been ruined by bureaucratic, architectural and urban decisions taken without sufficient thought.

The fact that these numune hospitals are still providing healthcare services today, and are still in possession of historical conservation value, makes them necessary to be revised, renovated and reused in accordance with the current architecture and conservation principles related to healthcare structures. Given that the principles of conservation have not been complied to any great extent to date, and that the structures constructed next to the first numune hospitals in Sivas and Erzurum after the 1950s have been demolished and replaced with other structures (such as car parks, etc.), it is clear that destruction or transformation options are preferred rather than ensuring the maintenance of the authentic values of the structures.

An assessment of the Ankara Numune Hospital (Block B), which is located on a campus with a distributed plan consisting of various healthcare structures, and has been conserved as a registered structure (constructed in 1933) that still provides healthcare services, will provide valuable information on the subject. As is clearly apparent from the layout plan, the closely and randomly spacing of the registered structure and the other structures that were added to the complex at a later date in a disorderly plan is a wrong approach that is frequently observed in the construction of numune hospitals. The links connecting the 
structures to each other involve small tunnel bridges, which have an adverse effect on the functional operation of the healthcare structure in question. Furthermore, the cafeteria and ATM that were sited opposite the entrance to the registered structure and at a very close distance completely block the facade of the building and prevent it from being seen as a whole (Figure 8). All these factors result in the registered structure being lost to the chaos, and vagueness in the perception of its architectural characteristics from up close.

Figure 8. (Left) Ankara Numune Hospital, connecting bridge added later to Block B (Author Archive, 2018); (Right) the cafeteria and ATMs that disrupt the perception of the facade (Mehmet Şener Archive, 2018).
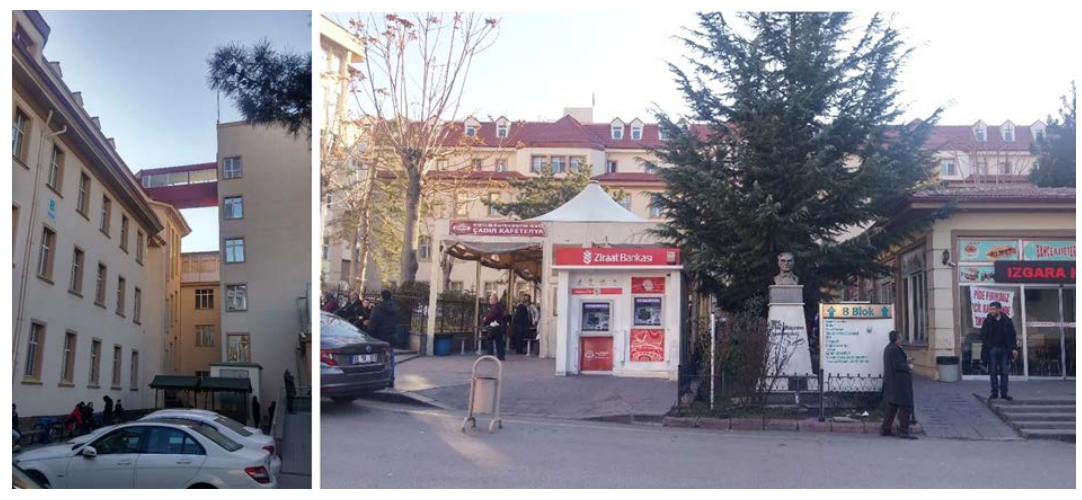

As is stated partially above, it should be underlined that locating other structures in very close proximity to the original hospital building of 1933 in a disorderly manner indicates that the value of the historical building was not adequately cared for. In contrast, the fact that the structures constructed on the campus were later designed with similar architectural characteristics ensured a common and consistent architectural language on the campus. The historical structure is seen as having undergone various interventions, and inappropriate construction materials have been used both on the envelope and within the structure, with two major renovations made over the last decade: one was the application of thermal insulation through the addition of plaster and paint, made approximately five years ago, and the other was the reconstruction of the roof, which had been lost completely during a fire that broke out in May 2016.

In a renovation made after the roof fire, a new inpatient ward was constructed in place of the attic and the wooden loadbearing system. Refunctioning the interior of the roof and covering the roof with tiles and metal cladding, if consistent with the original form, would be acceptable applications related to the function and architectural identity of the registered structure (Figure 9). On the other hand, it should be underlined that the cladding and engineering applications (electrical installation, ventilation, etc.) carried out to the facade damaged the authentic identity of the registered structure (Figures 10 and 11). The use of contemporary construction materials to the interior of the 
building at times to meet the new needs of the hospital resulted in an indoor environment that differed from its original form. It is apparent that the old (mosaic, marble, etc.) and new (PVC, aluminium profile, etc.) materials were used together, which is acceptable considering the functional requirements of the hospital.
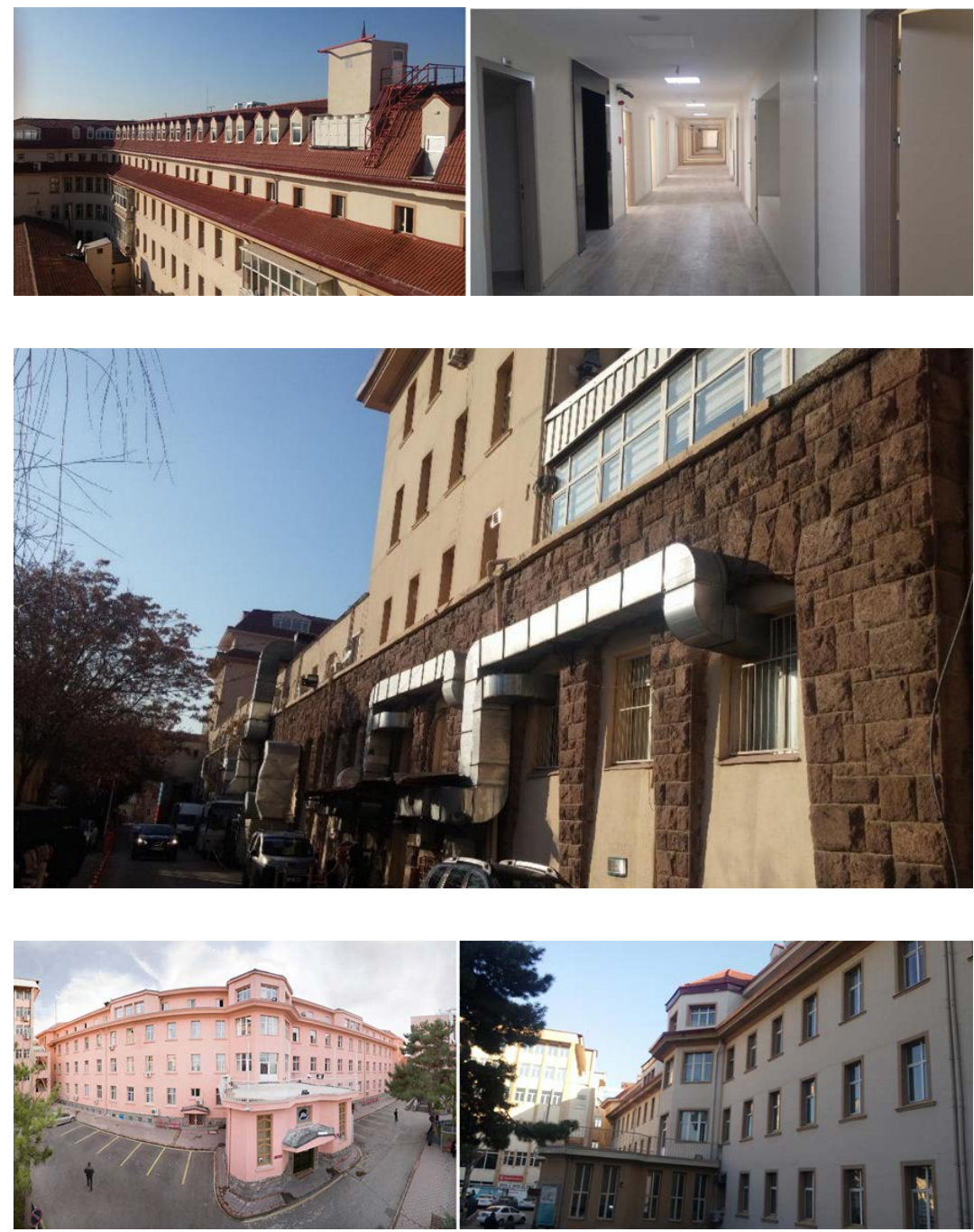

Various positive and negative aspects can be observed when the other three numune hospitals are examined from this perspective. While the facade of the Diyarbakır Numune Hospital is suffering from visible plaster and paint damage, the hospital's physical integrity and authentic form have been maintained, to a large extent (Figure 5). Currently in use as a psychiatry clinic, its windows have been fitted with iron grills, which when coupled with the ventilation devices that have been applied to the facade, can be said to have damaged the authenticity of the registered structure.
Figure 9. (Left) Ankara Numune Hospital, renovated roof after the fire in 2016 (Source: Author Archive, 2018); (Right) the new clinic constructed in the attic (Mehmet Şener Archive, 2018).

Figure 10. Ankara Numune Hospital, the view of the mechanical installation to the hospital facade (Mehmet Şener Archive, 2018).

Figure 11. (Left) Ankara Numune Hospital before insulating (Source: Atalay et.al, 2011); (Right) the current view after the insulating (Mehmet Şener Archive, 2018). 
Figure 12. Erzurum Numune Hospital, Erzurum, 2018, the deteriorations observed on the facade of the Erzurum Numune Hospital, which was transformed from a Gureba Hospital and is currently serving as a Family Health Center (Dilek Okuyucu Archive, 2018).

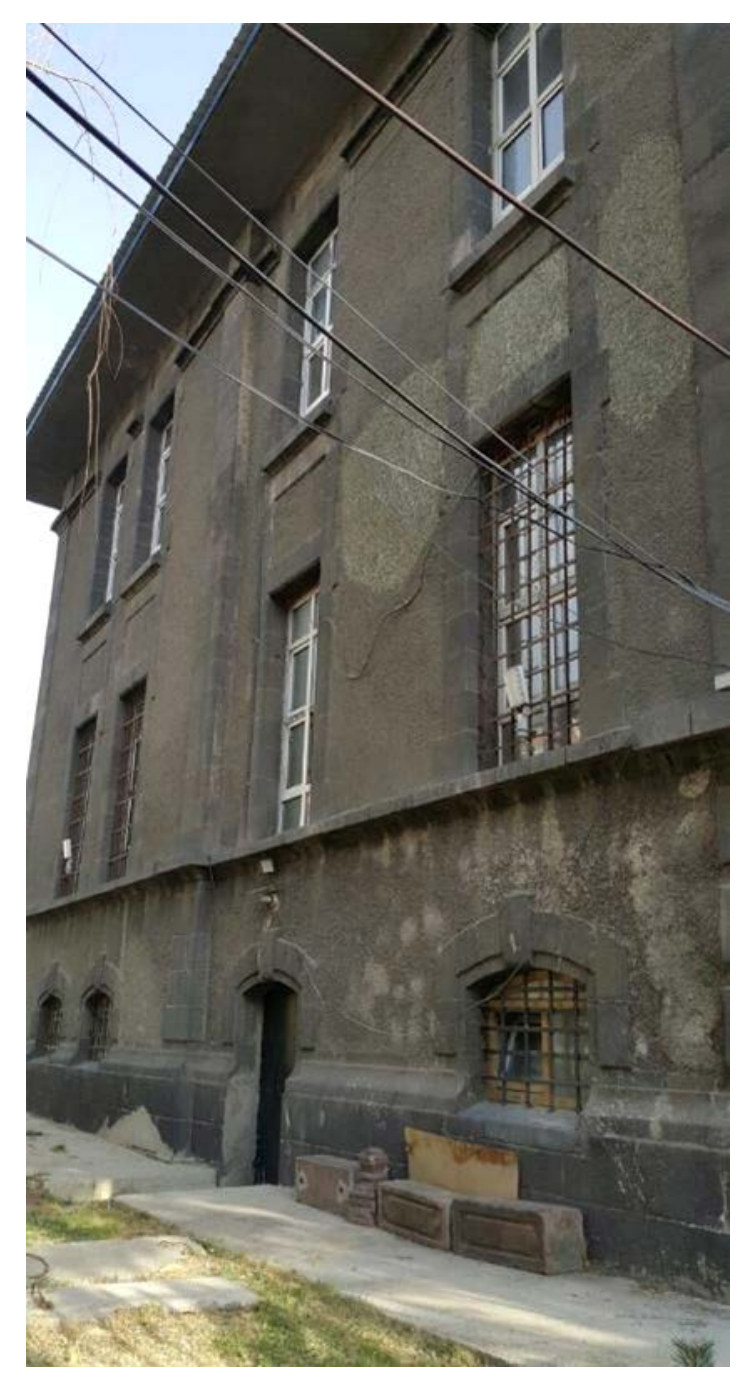

The Erzurum Numune Hospital building was transformed from a Gureba Hospital in 1924, and is currently being used as the Directorate of Public Health (Block C) and the Şerif Efendi Family Health Center. The deteriorations to its facades resulting from moisture ingress and the materials used are remarkable (Figure 12). Comparing the photograph of the structure taken in 1904 to its current appearance, it is apparent that one floor over the entrance has totally been removed from the structure completely, and its roof finishings have been replaced (Figures 6, 12 and 13). Considering the registered status of the building, it is likely that the said intervention was made prior to the date of registration. The roofing material and pitch were probably changed due to physical requirements. The Sivas Numune Hospital building (Block A), which was completed in 1952 and is still providing services, was registered and preserved by the "Regional Committee of Structure Conservation" in 2016. Structures that had been added in later years were demolished in two stages in 2017, although "it had been stated in a report that they were very safe and solid" (The first stage of the 
demolition led to serious hazards) (Budaktaş, 2017; Ensonhaber, 2017). The additional structures that had been built in close vicinity to the registered structure and served as the "Directorate of Public Health, Provincial Directorate of Health and Yüceyurt Family Health Center" no longer exist, having been demolished to make way for a 7,000-person mosque project scheduled to be constructed on the site (Figure 14) (Budaktaş, 2017). In 2018, as noted in a Guardian article on February 27, 2012 with the new developments, the demolishing of the building came up on the grounds that the existing registered building does not have the required earthquake resistance (Cumhuriyet, 2018).
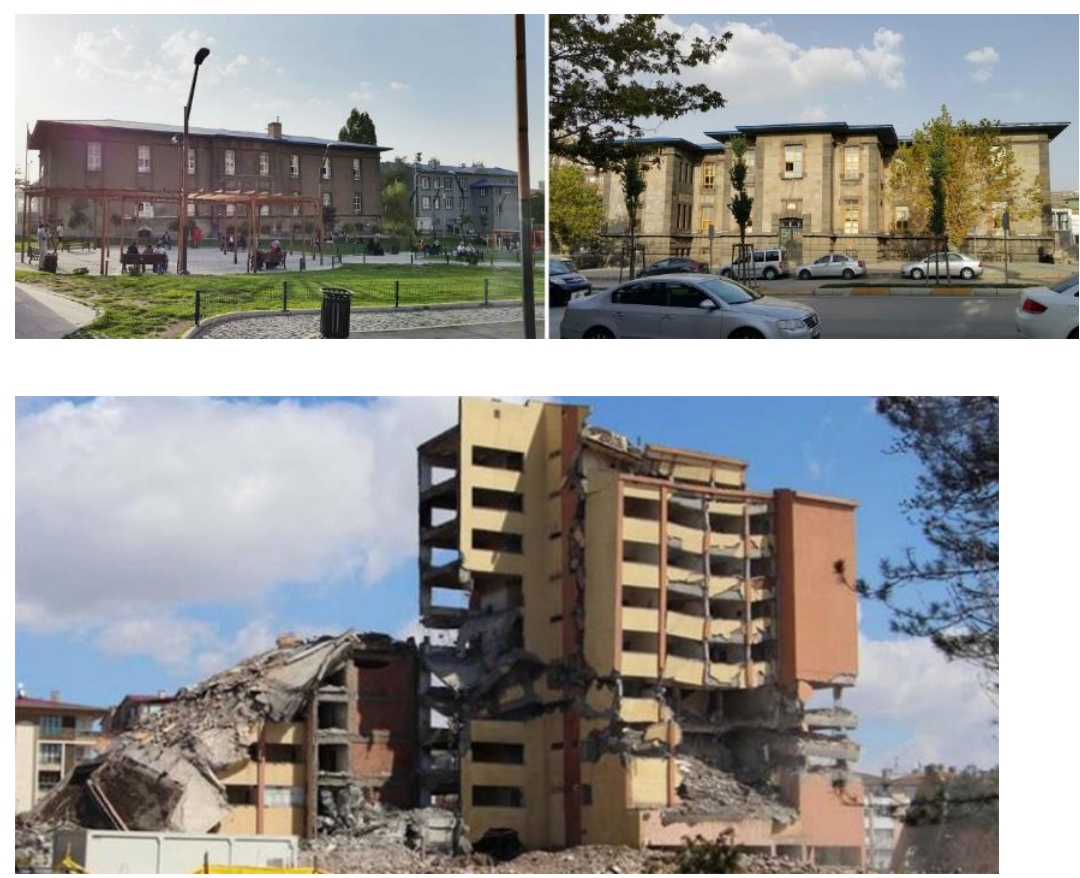

\section{NUMUNE HOSPITALS IN THE CONTEXT OF INTEGRATED CONSERVATION AND REUSE}

The structures of Ankara, Diyarbakır and Sivas Numune Hospitals that have survived so far, and the structures of the Erzurum and Sivas Numune Hospitals that have recently been demolished should be addressed as part of efforts aimed at the conservation of the modern architectural heritage. The studies and activities of DOCOMOMO (Documentation and Conservation of Modern Movement) related to the documentation and conservation of cultural assets from between 1920 and 1975 and representing modernism are guiding in this respect (Ergut, 2013; Omay-Polat \& Can, 2008). The numune hospitals addressed in the article are considered to be items of modern architectural heritage, in line with the concept defined in the Architectural Heritage Conservation Charter published by International Council of Monuments and Sites (ICOMOS) Turkey in 2013 as follows (ICOMOS-Türkiye, 2013).
Figure 13. (Left) Erzurum Numune Hospital, the current view of east elevation of the hospital (Dilek Okuyucu Archive, 2018); (Right) the current view of west elevation of the hospital (Dilek Okuyucu Archive, 2018).

Figure 14. Sivas Numune Hospital, demolition of the structures around the registered structure (Ensonhaber, 2017). 
"Modern architectural heritage is any structure, group of structures or complex that has been constructed since the beginning of the 20th century and exemplifies both international and national orientations and/or innovative techniques and technologies."

An analysis of the numune hospitals in line with this definition reveals that they can be considered modern architectural heritage on the grounds that they represent the national and international orientation at an urban and structural scale, have a historical identity, and reflect the development of healthcare technologies and healthcare architecture of the Republic of Turkey. The major problem related to these structures is that a common and participative approach that takes into account the values they possess is lacking, and a number of impediments to the conservation of these structures in social, administrative and architectural terms are encountered. As a result of the determining role played by economic value in the conservation of modern architectural heritage, conservation committees and other stakeholders with a say in the issue have in the past made questionable decisions regarding conservation approaches and applications, and this has led to significant problems concerning the conservation of structures, as underlined in the previous section. In order to eliminate the problems in question, it is necessary to make the integrated conservation approaches applicable. The Amsterdam Charter makes various statements on the principles of integrated conservation (ICOMOS, 1975). For instance, the importance of conservation of architectural heritage in urban planning is emphasized, and it is stated that the pursuit of a conservation approach that takes into account economic, social, managerial and legal aspects is the primary purpose of conservation. Additionally, recommendations are made for the prevention of sudden and non-economic improvement processes to ensure the continuous maintenance of architectural heritage.

Moreover, the refunctioning approach and the things to be considered related to the conservation of the urban fabric are emphasized, together with the economic aspects of conservation, as follows:

... structures should be given functions that are in harmony with the requirements of modern life without neglecting their character, and thus their existence should be secured ..." (ICOMOS, 1975).

Another aspect of this issue is the important role that should be assumed by local administrations related to integrated conservation. The Ministries and local administrations that are responsible for ensuring the conservation of Republican period structures should clearly publicize the decisions they take 
concerning applications, and discuss and evaluate the reasons for such decisions with conservation experts.

Accordingly, the necessary conservation approaches should be reformulated based on recommendations regarding the use of numune hospital structures and their vicinity that are still standing through stratification from the perspective of resource saving and the adaptation for new functions in accordance with the requirements of modern life. Buildings constructed in close proximity to registered structures that were later found to be worthless and were consequently demolished; public areas that were designed around such structures, such as car parks and green areas; and approaches prioritizing economic concerns are all harsh interventions against spiritual values and urban memory that do not comply with the provisions of the Amsterdam Charter.

An analysis of how each of the numune hospital structures has been reused shows that each structure is in a different condition. The Erzurum Gureba Hospital building, which is currently home to the Şerif Efendi Family Health Center, is still functioning in line with its originally intended use. Interventions such as the replacement of the roof and the cladding to the facades of the numune hospital building in Ankara, which continues to function as a healthcare facility, have damaged the authenticity of the structure to some extent. The building of the first numune hospital in Diyarbakır, which has not survived, can be considered as a lost architectural asset, and discussions concerning the demolition of Sivas Numune Hospital building on the grounds that there would be a risk of collapse in the event of an earthquake, are another dramatic reality in the context of the abovementioned discussions.

The decisions taken regarding the Erzurum and Sivas Numune Hospitals at the urban scale contradict the participative conservation principles related to interventions. As these examples suggest, the conservation of relatively older numune hospital structures on the grounds that they are registered, the demolition of the structures around them for the construction of green spaces and car parks, and explanations made to the public stating that such interventions are necessary, indicate the implication of unilateral policies by the public authorities. The interventions and the rapid decisions made in such cases have eliminated the possibility of creating a memory that would allow an analysis of the architectural and technological development of cities in general, and healthcare structures in particular, and reveal the healthcare services provided to those cities. Such applications go against the principles of universal conservation, as another serious dimension of the problem of their 
implementation without sufficient planning or feasibility studies with regard to long-term economic gains.

\section{EVALUATION AND CONCLUSION}

The numune hospitals that were created through transformation of Gureba hospitals in 1924, as well as the construction of additional structures around them in the following periods, are important assets of cultural and architectural heritage that reflect the early years of the Republic and served as examples for the subsequently constructed hospitals. While it is evident that the architectural styles adopted under the guidance of the state in the early Republican period failed to spread to any great degree to the provinces of Anatolia, excluding Ankara, it should be underlined that the numune hospitals that were constructed in various provinces contributed to the dissemination of the architectural language demanded by Ankara for public buildings to various cities of the country, to some extent.

Today, it is known that there are various conservation and restoration methods for the protection of the comprehensive modern architectural heritage portfolio, and the numerous healthcare structures it contains. That said, considering the rapid transformations that the design standards, services and technologies witnessed in the health facilities, it is obvious that these hospitals, the newest of which was constructed in 1952, would not meet the current requirements of health facility architecture and be suitable for functional health service. There is little doubt that various technical and architectural revisions are required in the numune hospitals addressed in this study if the provision of quality healthcare services that can meet the current standards is to be achieved. Additionally, solutions such as the transformation of old hospitals into facilities that can support the current hospital program may also be implemented. Taking into account contemporary approaches and the advanced conservation and renovation techniques being employed today, it is possible to make use of these structures by transforming their functions and maintaining their authentic values through proper applications. If they are still part of a complex in which healthcare services are provided, they can be integrated into the existing functional structure.

One of the most important points revealed by this study is that a large majority of the first group of numune hospitals covered herein have survived to the present day, despite some improper interventions. In contrast, the structures that were added to or reconstructed under the same name were not treated with the same degree of sensitivity, and most have been demolished. This indicates that a well-defined framework regarding that which structures are to be conserved according to which criteria could 
not be created, and that the decision-making mechanism focused solely on the conservation of the oldest structures, or those constructed in the early years of the Republic. At this point, a theoretical framework and a consistent perspective concerning the conservation or demolition of numune hospitals should be presented. While one perspective of this subject focuses on the historical and cultural conservation value of these structures, another analyzes whether they have the necessary physical qualities to support the continued provision of modern healthcare services, as their primary function. First of all, it should be noted that the sustainability of these structures, which were registered as assets of cultural and architectural heritage dating back to the early years of the Republic should be ensured, provided that the authentic form of all components used at the time of their construction, is conserved. However, it is observed that although each of the structures clearly have conservation value, some were not conserved by the Ministry of Health or any other relevant authority, and consequently, have been subjected to negligent interventions. Since these interventions, made at various times in parallel with the development of healthcare technologies, were not in line with approaches that prioritized the identity of the registered structure, the original structures have been subjected to various levels of damage.

These structures that initially provided all of the services expected of a fully equipped hospital are today used for the provision of lower level healthcare services, with administrative and polyclinic services provided in the Sivas Numune Hospital; low profile polyclinic services provided with the function of a family health center in Erzurum; and administrative and inpatient ward services provided in Ankara. Considering the conditions and the requirements in the provision of healthcare services, it should be underlined that such functional transformations in which conservation principles and requirements are taken into account, are possible, and even necessary. In contrast, the Diyarbakır Numune Hospital is currently functioning as a psychiatric hospital, and differs from the other numune hospitals in terms of its use.

When the bulk of data obtained in the study is assessed as a whole in regards to the conservation policies to be followed for numune hospitals that have functional priority and still provide healthcare services, and equivalent public structures, it is the best to pursue an approach that "focuses primarily on the conservation of everything, that enables the formation of 'demolition approval committees' rather than conservation committees, and that allows the demolition of structures when required and survival of the others in their historical continuity...", as stated by Altan with respect to the conservation 
of modern architectural heritage (Turgut, 2017). While it is evident that the utmost care should be taken to ensure the conservation, reuse and refunctioning of these structures with modern architectural heritage status, the ways to take common decisions by making comprehensive discussions related with the demolition of such structures are opened if they are not durable and in a state in which they can functionally provide services, cause harm to the architectural and urban fabric around them both visually and functionally, and no conservation or refunctioning interventions could improve their status. That said, application practices that attribute heritage value only to the numune hospitals constructed in and before the early Republican period, and which focused on their conservation, but regard the numune hospitals constructed after 1950s that were the products of a modern architecture as demolishable, is in contradiction with this approach, and has led to the loss of urban memory from the times of their construction and the current projection of the historical richness. In order to prevent approaches that result in the destruction of historical bridges between the past and the present, it should be ensured that the concepts of heritage and value are defined in a broader contextual framework, and that conservation principles are shaped within the framework of such definitions.

\section{REFERENCE}

Altay, S. (2015). Atatürk Dönemi Sağlık Politikalarının Halka Yansımasında Öncü Kurumlar: Numune Hastaneleri (19241938). Ankara University.

Başar, Z. (1979). "Erzurum Gureba Hastanesi ve Sonrası", Ankara Üniversitesi Tıp Bülteni, 4: 541-545.

Bozdoğan, S. (2012). Modernizm ve Ulusun Inşası Erken Cumhuriyet Türkiye'sinde Mimari Kültür. Metis Yayınları.

Budaktaş, Y. (2017). Numune Hastanesi Binası. http://www.siv asirade.com/haber/numune-hastanesi-binasi-14872.html

Çağlayan, E. (2013). “Diyarbakır'da Sağlık Alanındaki Gelişmeler [1923-1946] ", The Journal of Academic Social Science Studies, 6(6): 351-365. https://doi.org/http://dx.doi.o $\mathrm{rg} / 10.9761 / \mathrm{JASSS} 1673$

Cengizkan, A. (2011). Türkiye İçin Modern ve Planlı Bir Başkent Kurmak: Ankara 1920-1950 Die Gründung einer modeernen und nach Plan errichteten Haupstadt für die Türkei: Ankara 1920-1950. In L. Alpagut \& A. Wagner (Eds.), Bir Başkentin Oluşumu: Avusturyal, Alman ve Ísviçreli Mimarların Ankara'daki İzleri = Das Werden einer Hauptstadt: Spuren deutschsprachiger Architekten.

Cumhuriyet. (2018). Numune Hastanesi'nin eski binası için yıkım tartışması. 
http://www.cumhuriyet.com.tr/haber/turkiye/913573/N umune_Hastanesi_nin_eski_binasi_icin_yikim_tartismasi.ht $\mathrm{ml}$

Dündar, C. (2006). Illk Büyük Taahhüt İşim: Ankara Numune Hastanesi, Özel Arşivinden Belgeler ve Anılarıyla Vehbi Koç. İstanbul: Doğan Kitap.

Ensonhaber. (2017). Sivas'ta hastane binası yıkımını çay içerek izlediler. https://www.ensonhaber.com/sivasta-hastanebinasi-yikimini-cay-icerek-izlediler-2017-04-02.html

Ergut, E. A. (2013). "Yirminci Yüzyıl Modern Mimarlık Mirası Korunmalıdır! DOCOMOMO_Türkiye: 10 Yılın Ardından...", Mimarlık, 371 http://www.mimarlikdergisi.com/index.cfm ?sayfa $=$ mimarlik\&DergiSayi $=385 \&$ RecID $=3160$

ICOMOS-Türkiye. (2013). Mimari Mirası Koruma Bildirgesi. http://www.icomos.org.tr/Dosyalar/ICOMOSTR_0623153 001387886624.pdf

ICOMOS. (1975). "The Declaration of Amsterdam (1975). In Congress on the European Architectural Heritage", 12(October). https://www.icomos.org/en/and/169-thedeclaration-of-amsterdam

Kamel-Ahmed, E. (2015). What to conserve?: Heritage, memory, and management of meanings. Archnet-IJAR. https://doi.org /10.26687/archnet-ijar.v9i1.469

Küçükuğurlu, M. (2016). Erzurum'un Yüzleri Belediye Reisi Şerif Efendi. Atatürk University.

Madran, E. (2006). "Modern Mimarlık Ürünlerinin Belgelenmesi ve Korunması Süreci için Bazı Notlar”, Mimarlık, 332: 2022.

Omay-Polat, E. E., \& Can, C. (2008). "Modern Mimarlık Mirası Kavramı: Tanım ve Kapsam", Megaron, 3(2): 177-186.

Sayek, F. (1998). Türk Tabipler Birliği Tarihe Giriș. Türk Tabipler Birliği. https://www.ttb.org.tr/ttb_tarihi/giris.html

Turgut, E. A. (2017). Modern Mimarlık Mirası Korunmalı mı? XXI Mimarlık, Tasarım ve Mekan. https://xxi.com.tr/i/modernmimarlik-mirasi-korunmali-mi 


\section{Resume}

Mehmet Şener received his B.Arch from Middle East Technical University, Department of Architecture (2003). Earned his master's degree (2006) in History of Architecture programme and PhD (2013) degree in History of Architecture programme from the same school. Currently works as an assistant professor at Kocaeli University Faculty of Architecture and Design. Major research area is early republican period architecture.

Emre Kishalı received his B.S. from Middle East Technical University, Department of Civil Engineering (2005). Earned his master's degree (2007) on Architectural Engineering and PhD (2011) degree on Restoration in the Building Engineering programme at Politecnico di Milano. Currently works as an assistant professor at Kocaeli University Faculty of Architecture and Design. Major research area is conservation of architectural heritage. 